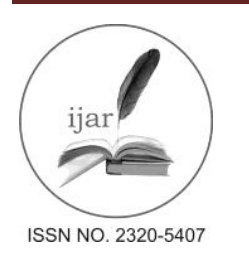

Journal homepage: http://www.journalijar.com
Journal DOI: 10.21474/IJAR01

INTERNATIONAL JOURNAL

OF ADVANCED RESEARCH

RESEARCH ARTICLE

\title{
ASSESSMENT OF THE ANTIOXIDANT AND ANTIBACTERIAL ACTIVITIES OF PETIVERIA ALLIACEA AND VISCUM ALBUM (MISTLETOE).
}

Francis JideFaleye* and Ayomadewa Mercy Olatunya

Department of Chemistry, Ekiti State University, P.M.B 5363, Ado-Ekiti, Ekiti State, Nigeria.

\section{Manuscript Info}

Manuscript History:

Received: 12 March 2016

Final Accepted: 22 May 2016

Published Online: May 2016

Key words:

Antioxidant, Petiveriaalliacea,

Viscum album, antimicrobial,

anticancer.

*Corresponding Author

Francis JideFaleye.

\begin{abstract}
The antioxidant and antimicrobial activities of the methanolic extracts of Petiveriaalliacea (Garlic guinea weed) and Viscum album (Mistltoe) from cocoa (Theobroma cacao) were investigated. Both samples showed good levels of DPPH radical scavenging activity with $\mathrm{IC}_{50}$ of $0.116 \mathrm{mg} / \mathrm{ml}$ and $0.120 \mathrm{mg} / \mathrm{ml}$ for $\mathrm{V}$. album and P. alliacea respectively. The extract of $\mathrm{V}$. album inhibited Pseudomonas aeruginosa, Escherichia coli, Klebsiellasp., Salmonella sp.,Shigellasp.,Proteus sp., and Staphylococcussp. with zones of inhibitions ranging from 3 to $25 \mathrm{~mm}$ at extracts concentrations of $62.5,125$, 250 and $500 \mathrm{mg} / \mathrm{ml}$. The zones of inhibitions for P. alliacea ranged from 3 to $24 \mathrm{~mm}$ for the same extract concentrations. V. albumhave the highest inhibition against E. coli and least inhibition against Staphylococcus sp., while P. alliacea have the highest inhibition against Shigellasp. And the least inhibition against Staphylococcus sp.
\end{abstract}

Copy.Right,IJAR, 2016...All rights reserved.

\section{Introduction:-}

Potential of herbs and other plant-based formulations have been increasingly recognized in prevention and treatment of human diseases including cancers. The discipline of ethnopharmacology, the study of biologically active agents traditionally employed or observed by man, has in recent years received increased attention, and there is presently a widespread interest in medicinal plants used by different cultures.

Extracts from plants have been found to contain minerals and primary metabolites but not only these; they have also been found to contain a diverse array of secondary metabolites with antioxidant potential and these have made the medicinal value of plants to assume a more important dimension in the past few decades (Akinmoladunet al., 2007). Antioxidant substances act as protective shield for our bodies against certain diseases like cardiac disease, atherosclerosis, cancerand in the aging (Marturet al., 2011). This they do by removing the deleterious effect of free radicals within our body. They slow or retard the organic matter oxidation promoted by these free radicals by removing the excess free radical intermediates and inhibit other oxidation reactions by going through oxidation themselves (Fasolaet al.,2011).Free radicals are involved in the pathogenesis of a large number of diseases thus a potent scavenger of free radicals may serve as a possible preventive intervention for diseases (Charturvediet al., 2015).

Several plants and vegetables which are used in traditional medicine for therapeutic purposes have antioxidant activity and their therapeutic effect have been attributed to their antioxidant activity.

Petiveriaalliacea is a species of flowering plant in the pokeweed family, phytolaccaceae(Wikipedia, 2015). It is a native to Florida and the lower Rio Grande valley of Texas in the United State, Mexico, Central America. It is commonly called Guinea Hen Weed the Yorubas call it Ewesoro. 
The plant has several applications both in medicine and industry. It is used in teas, extracts and capsules. It has been used to reduce inflammation and pain. It has antibacterial ability, antifungi and antiviral effects (Schmelzer and Gurib- Fakim, 2008).

Schmelzer and Gurib- Fakim (2008) have revealed that the plant has tendency to reduce blood sugar level and also eliminate cancer cells. The plant is also used as bait and insect repellant (Wikipedia, 2015).

Mistletoe (Viscum album) popularly called Afomo by the Yorubas is an evergreen semi-parasitic plant normally found growing on a variety of trees; especially pines, cocoa etc. Mistletoe belongs to the family santalaceae and there are different species of the plant.

Extract of this plant have been used for cancer therapy, this was due to the immunostimulatory and cytotoxic properties of the plant ( Eggenschwileret al., 2007). It has been used as anticancer, antidiabetic, antihypertensive and as all-purpose herb (Kafanu, 1993). It is used in Ondo State as topical antibiotic in form of pastes for the treatment of wounds and other skin infections (Yusuf et al., 2013a).

Synthetic antibacterial used nowadays are associated with different complications leading to different diseases like blood cancer and upper gastrointestinal complications. Not only that, they are expensive and are not within the reach of the poor masses, there is therefore need for cost effective and natural antibiotic. Some of the underutilized plants grown in Nigeria have these properties.

The aim of the present study was to assess the antioxidant and antimicrobial activities of these plants and to compare their activities.

\section{Materialsand Methods:- Collection of Samples:-}

Fresh leaves of Viscum album (mistletoe) from the host, Theobroma cacao (cocoa), and the Petiveriaalliacea, were collected from different locations in Ekiti State and identified in the herbarium section of the Department of Plant Science, Ekiti State University.

\section{Extraction of Samples:-}

$100 \mathrm{~g}$ of each powdered samples was extracted with $200 \mathrm{ml}$ of concentrated methanolic solution. The mixture was left in the dark for 72 hours after which it was filter and the filtrate was concentrated using rotary evaporator.

\section{Antioxidant Potential Determination:-}

The free radical scavenging ability of the samples against 1, 1-diphenyl -2- picrylhydrazyl (DPPH) free radical was evaluated as described by Gyanfinet al., (1999) with slight modification. Briefly $1 \mathrm{ml}$ of $3.9 \mathrm{mg} / 100 \mathrm{ml}$ of the methanolic solution containing DPPH radicals was mixed with different volumes of $0.1 \mu \mathrm{l} / \mathrm{ml}$ of the methanolic extract of the samples, the volumes of the samples used ranged between $50-200 \mathrm{ml}$. The mixture was left in the dark for 30min and the absorbance was measured at $516 \mathrm{~nm}$. BHT was used as positive control. The DPPH free radical scavenging ability was subsequently calculated with respect to the reference and the $\mathrm{IC}_{50}$ was also calculated. The percentage DPPH radical-scavenging activity was calculated as:

Where:

$$
\frac{\mathrm{Abs}_{\mathrm{ref}}-\mathrm{Abs}_{\mathrm{sam}}}{\mathrm{Abs}_{\mathrm{ref}}} \times 100
$$

Abs $_{\text {ref }}-$ Absorbance of reference; $\mathrm{Abs}_{\mathrm{sam}}-$ Absorbance of sample

\section{Determination of Antibacterial Activity:-}

The antibacterial activities of the methanolic extracts were determined using the agar diffusion method as described by Faleyeet al., (2015). Antibacterial activity was assessed by measuring the diameter of the zone of clearance to the nearest wholemillimetre. 


\section{Results and discussions:-}

The scavenging ability of each methanolic extracts against stable DPPH in methanolic solution is presented in Figure 1. The result followed a dose -dependent pattern, the methanolic extract of $\mathrm{V}$. album (Mistletoe) $\mathrm{IC}_{50}$ of 0.116 $\mathrm{mg} / \mathrm{ml}$ performed better than Petiveriaalliacea with $0.120 \mathrm{mg} / \mathrm{ml}$. Nevertheless, this activity are slightly lower than that of BHT used as positive control $\left(\mathrm{IC}_{50}=0.072 \mathrm{mg} / \mathrm{ml}\right)$. This showed that V.album had better antioxidant activity than Petiveraalliacea. This result is in agreement with the result of Yusuf et al., (2013b) on the antioxidant of mistletoe grown on cola.



Fig.1:- Percentage radical scavenging activity of Viscum album and Petiveriaalliacea

The effect of antioxidants on DPPH radical scavenging activity was thought to be due to their hydrogen donating ability. Antioxidants perform their protective function on living cells by preventing the production of free radicals or by neutralizing the free radicals produced in the body (Oboh and Rocha, 2007).

Figures 2 and 3reports the inhibition zones of V. album and P. alliacea for seven strains of Gram-positive or Gramnegative bacteria using the diffusion technique on solid media as well as the results of the antimicrobial activities of Viscum album and Petiveriaalliacea extracts in agar diffusion method against the concentrations of $62.5 \mathrm{mg} / \mathrm{ml}$, $125 \mathrm{mg} / \mathrm{ml}, 250 \mathrm{mg} / \mathrm{ml} 500 \mathrm{mg} / \mathrm{ml}$. The extract ofV. album demonstrated higher antimicrobial activities against Pseudomonas aeruginosa, Escherichia coli, and kllebsiella sp. than the activities of P. alliacea against the microorganisms with the same concentrations. V. album at concentration of $62.5 \mathrm{mg} / \mathrm{ml}$, showed inhibition against the gram-negative bacteria P. aeruginosa and Klebsiella sp. butP. alliacea did not show any inhibition against the organisms. This showed that even at low concentration;V. album can still inhibit these bacteria. 


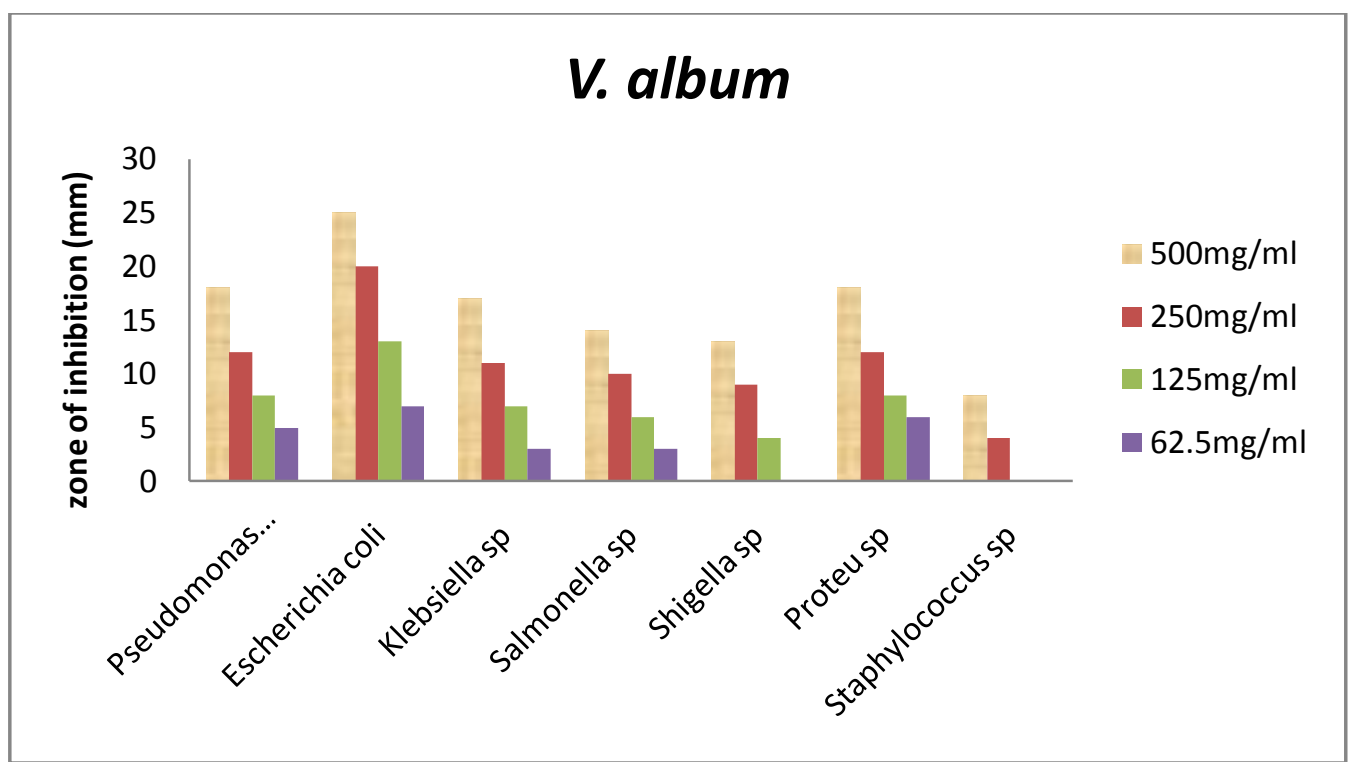

Fig. 2:- Antimicrobial activity of V. album.

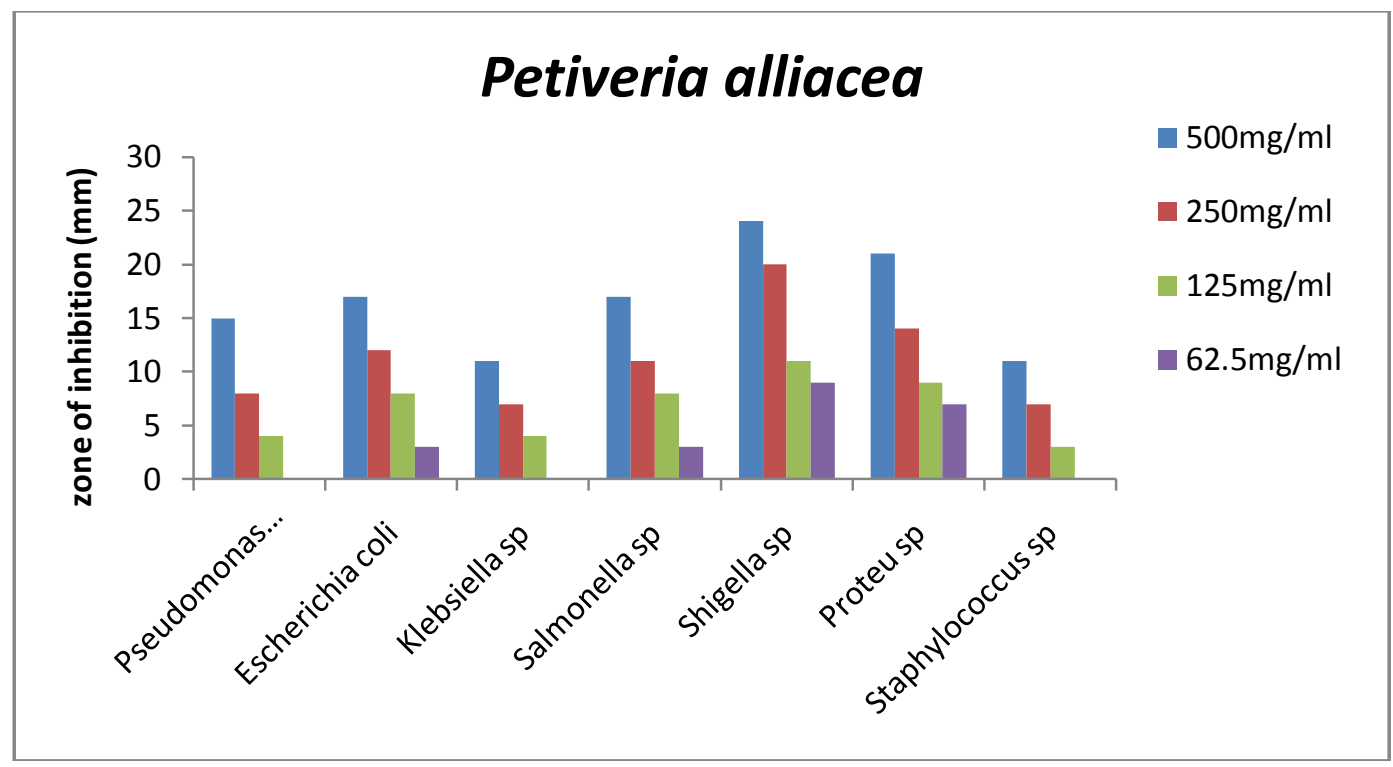

Fig 3:- Antimicrobial activity of P. alliacea.

The DPPH radical scavenging activity and antioxidant activity of V.album extract were comparable to those of P. alliacea which has been notably known as a world acclaimed anticancer agent(Schmelzer and Gurib, 2008; Johnson, 1999). In contrast to the relatively low inhibition of V. album for gram - positive bacteria belonging to the general Staphylococcus sp;Pseudomonas,Escharichia, Kleibsiella,Salmonella and Proteus were inhibited by V. album with zone of inhibition ranging from 3 to $25 \mathrm{~mm}$. Our findings showed that where P.alliaceais not available V. album can also be used as anticancer and antiviral agent owing to its antioxidant and antimicrobial activity. The antioxidant and antimicrobial abilities of these two underutilized plants justify their various traditional uses.

\section{Conclusion:-}

The free radical scavenging ability and antimicrobial activities of these samples are indication that they have good antioxidant and antibacterial properties.They are natural and economic sources of antioxidant and antibacterial, therefore they can find better application in food industry, pharmaceutical industry and medicine. 


\section{References:-}

1. Akinmoladun A.C., Ibukun E.O., Akinrinlolo B.L., Onibon T.R., Akinboboye A.O., Obuotor E.M., Farobi E.O. (2007): Chemical constituents and antioxidant activity of Alstoniaboonei. Afr. J Biotechnol.6 (110): 11971201.

2. Chaturvedi N., Gupta P., Shukla K. (2015): Free radical scavenging and antioxidant activity of underutilized processed Jack Bean (Canavaliaensiformis) and Barnyard Millet (Echinochloafrumentacae) flour extracts. IJIPPR4(2):24 -34.

3. Eggenschwiler J.I., Balthazar B., Stritt D., Pruntsch M., Rames K., Urech L.Rist, Simoes- Wust A.P., Viviani A. (2007): Mistletoe lectins are not the only cytotoxic component in fermented preparations of Viscum album from white fir(Abiespectinata).BMC complemsentary and Alternative medicine7(14):1-7.

4. Faleye F.J., Odeyemi A.T., Olagboye S.A. (2015): Studies of the Chemical, phytochemical and antimicrobial activities of Viscum album (Mistletoe) on five different host plants. Journal of Chemical Biological and Physical Sciences (JCBPS) 5(4):4172 - 4180.

5. Fasola T.R., Oloyode G.K., Aponjolosun B.S. (2011): Chemical composition, toxicity and antioxidative activities of essential oils of stem bark of Nigerian species of Guava (Psidiumguajava Linn). Experimental and Clinical Sciences 10: 34- 43.

6. Gyamfin A., Yonamine M., Aniya Y. (1999): Free radical scavenging action of medicinal herbs from Ghana: Thoonningiasanquinea on experimentally - induced liver injuries. General Pharmacology32: 661-667.

7. Johnson L. (1999):Anamu: Petiveriaalliacea. Woodland Publishing Spain p 1-14

8. Kafanu E. (1993): Herbal remedies; The Guardian Thursday June 31993 p 24.

9. Mathur A., Verna S.K., Purohit, R., Gupta V., Dua V.K., Prasad G.B., Mathur D. (2011): Evaluation of in vitro antimicrobial and antioxidant activities of peel and pulp of some citrus fruits. IJPI'S J Biotechnol and Biotherapeutic1(2):1-17.

10. Oboh G, Rocha J.B.T. (2007): Poly phenols in red pepper(Capsicum annum) varaviculane (Tepkin) and their protective effect on some pro-oxidants induced lipid peroxidation in brain and liver. Eur.Food Res. Techno, 225(2): 239-247.

11. Schmelzer G.H., Gurib- Fakim A. (2008): Medicinal Plants. Plant Res Tropical Afr.p 412-415.

12. Wikipedia, the free encyclopedia (2015): Mistletoe, Available on www.wikipedia.org/wiki/mistletoe. Retrieved $16^{\text {th }}$ July, 2015.

13. Yusuf L., Oladunmoye M.K., Ogundare A.O., Akinyosoye F.A., Hassan G.F., Momoh A.O. (2013a): Comparative antibacterial studies of mistletoes growing on two different host plants in Akure North, Nigeria. Int. J of Med and Medical Sci. 3(5):009-011.

14. Yusuf L, Oladunmoye M.K., Ogundare A.O., Akinyosoye F.A., Daudu O.A.Y., Hassan G.A. (2013b):Antimicrobial and antioxidant properties of mistletoe (viscum album) growing on cola (cola nitida) tree in Akure North, Nigeria. J Micro Res and Reviews. 1(3): 35- 41. 